\title{
INTERFERENSI GRAMATIKAL BAHASA JAWA DALAM BAHASA INDONESIA PADA KARANGAN LAPORAN PESERTA DIDIK SMP
}

\author{
Hanif Triyanto ${ }^{1}$, Endang Nurhayati ${ }^{2}$ \\ ${ }^{1}$ SMP Negeri 1 Salaman. Jalan Pangeran Diponegoro, Kabupaten Magelang, 56162, Indonesia. \\ ${ }^{2}$ Jurusan Pendidikan Bahasa Jawa, Universitas Negeri Yogyakarta. Jalan Colombo No. 1, \\ Karangmalang, Yogyakarta 55281, Indonesia. \\ * Korespondensi Penulis. Email: hamikato@gmail.com, Telp: +6281328033196
}

\begin{abstract}
Abstrak
Penelitian ini bertujuan untuk mendeskripsikan (1) bentuk-bentuk interferensi morfologi bahasa Jawa dalam bahasa Indonesia, (2) bentuk-bentuk interferensi sintaksis bahasa Jawa dalam bahasa Indonesia, dan (3) faktor penyebab terjadinya interferensi morfologi dan sintaksis bahasa Jawa dalam bahasa Indonesia pada hasil karangan menulis laporan. Penelitian ini merupakan penelitian deskriptif kualitatif. Subjek penelitian adalah hasil karangan pada pembelajaran menulis laporan berbahasa Indonesia Objek yang diteliti adalah bentuk-bentuk interferensi morfologi dan sintaksis bahasa Jawa dalam bahasa Indonesia beserta faktor-faktor penyebabnya. Pengumpulan data dilakukan dengan teknik baca dan catat serta pengisian angket. Data dianalisis menggunakan metode padan intralingual dengan teknik Hubung Banding Membedakan. Keabsahan data diperoleh melalui ketekunan pengamatan dan pemeriksaan sejawat. Hasil penelitian ini menemukan bentuk-bentuk interferensi morfologi bahasa Jawa dalam bahasa Indonesia meliputi proses morfologis dan morfofonemis. Interferensi proses morfologis meliputi afiksasi dan reduplikasi. Interferensi proses morfofonemis berupa peluluhan fonem pada awal kata berprefiks $\{\mathrm{N}$ \}.Interferensi sintaksis meliputi pola konstruksi frasa, penggunaan preposisi, konjungsi, dan partikel. Faktor penyebab terjadinya interferensi morfologi dan sintaksis bahasa Jawa dalam bahasa Indonesia adalah faktor linguistik meliputi penguasaan B1, rendahnya penguasaan B2 dan faktor kedwibahasaan. Faktor nonlinguistik meliputi kebiasaan, lingkungan, sikap bahasa, motivasi, guru, dan evaluasi pembelajaran.
\end{abstract}

Kata Kunci: interferensi, morfologi, sintaksis, dan faktor penyebab

\section{THE GRAMMATICAL INTERFERENCE OF JAVANESE LANGUAGE IN INDONESIAN ESSAY OF JUNIOR SECONDARY SCHOOL STUDENTS'}

\begin{abstract}
This research was aimed to describe (1) Javanese morphological interference forms in Indone-sian language, (2) Javanese syntactic interference forms in Indonesian language, and (3) the factors cousing Javanese morphological and syntactic interference in Indonesian essay. This research is a qualitative descriptive study. The subject of this research were the essay as learning outcomes. The objects of this research were Javanese morphological and syntactic interference forms in Indonesian language and the factors that cause the morphological and syntactic interference. The data were collected by reading and writing techniques and questionnaires. The data were analyzed using the unified intralingual method with Connecting Appeal Differentiating techniques. The validity of the data obtained from a continous observation and peer review. The results of this research find the mor-phological and syntactical interference. The morphological interference includes morphologies and morphophonemic processes. The morphologies interference process includes affixation and reduplica-tion. The morphophonemic interference process was the result of phoneme at the beginning of the word with prefix $\{N-\}$. The syntactical interference includes the pattern of phrase constructions, the use of prepositions, conjunctions, and particles. The causes of Javanese morphological and syntactic interference in Indonesian language are linguistic factors including the mastery of L1, low mastery of L2, and bilingualism factors. Nonlinguistic factors include habits, environments, language attitudes, motivations, teachers, and learning evaluations.
\end{abstract}

Keywords: interference, morphological, syntactic, and causes factors

How to Cite: Triyanto, H., \& Nurhayati, E. (2016). Interferensi gramatikal bahasa Jawa dalam bahasa Indonesia pada karangan laporan peserta didik SMP. LingTera, 3(1), 23-36. doi:http://dx.doi.org/10.21831/lt.v3i1.8471

Permalink/DOI: http://dx.doi.org/10.21831/lt.v3i1.8471 


\section{LingTera, 3 (1), May 2016 - 24}

Hanif Triyanto, Endang Nurhayati

\section{PENDAHULUAN}

Hasil survei di salah satu SMP Negeri di Kabupaten Magelang menunjukkan bahwa kebiasaan membaca dan menulis peserta didik tergolong masih rendah. Rendahnya kebiasaan membaca dapat diketahui dari rendahnya angka kunjungan peserta didik ke perpustakaan. Hal ini diduga dipengaruhi oleh kurangnya guru dalam memberikan tugas yang menuntut peserta didik untuk aktif membaca seperti tugas membuat rangkuman, sinopsis novel, atau tugas yang lain. Kegiatan lomba yang menantang peserta didik untuk aktif membaca pun jarang diadakan. Sedangkan, cara seperti itu diduga dapat merangsang minat baca yang pada akhirnya diharapkan dapat meningkatkan kemampuan membaca peserta didik.

Suryaman (2012, p.36) menyatakan bahwa "permasalahan terbesar dan mendasar di dalam pembelajaran bahasa Indonesia saat ini adalah permasalahan berkenaan dengan kemampuan dan kebiasaan membaca dan menulis". Masalah kemampuan dan kebiasaan membaca dan menulis ini perlu segera dipecahkan karena besarnya dampak yang ditimbulkan bagi pengembangan mutu pendidikan. Pemerintah melalui PP No. 19 tahun 2005 Pasal 25 ayat 3 menyatakan bahwa "Kompetensi lulusan untuk mata pelajaran bahasa menekankan pada kemampuan membaca dan menulis yang sesuai dengan jenjang pendidikan". Dalam Pasal 21 Ayat 2, pemerintah juga mengatur bahwa "Pelaksanaan proses pembelajaran dilakukan dengan mengembangkan budaya membaca dan menulis".

Rendahnya kemampuan membaca peserta didik akan berdampak pada rendahnya kemampuan menulis mereka. Suryaman (2012, p.39) menyatakan "Jika kemampuan dan kebiasaan membaca belum berkembang pada diri siswa, dapat dipastikan bahwa kemampuan dan kebiasaan menulis tidak akan berkembang dengan baik." Ini menunjukkan betapa eratnya hubungan kemampuan dan kebiasaan membaca dengan kemampuan dan kebiasaan menulis. Hal ini dapat diartikan bahwa untuk bisa menjadi penulis yang baik diperlukan kemampuan dan kebiasaan membaca yang baik. Lebih lanjut Suryaman menyampaikan pandangan umum yang meyakini adanya hubungan positif antara perkembangan kemampuan membaca dan menulis, yakni pada umumnya penulis yang baik adalah pembaca yang baik. Oleh karena itu, dalam diri peserta didik yang belum tertanam kemampuan dan kebiasaan membaca yang baik, akan sulit untuk dapat menghasilkan sebuah tulisan yang baik.

Menulis merupakan keterampilan berbahasa yang tergolong sulit. Untuk dapat menulis dengan baik, seseorang minimal harus menguasai dua hal yaitu penguasaan atas ide atau gagasan yang akan ditulis dan penguasaan tentang kaidah penulisan. Iskandarwassid \& Sunendar (2011, p.248) menyatakkan bahwa aktivitas menulis merupakan suatu bentuk manifestasi kemampuan dan keterampilan berbahasa yang paling akhir dikuasai oleh pembelajar bahasa setelah kemampuan mendengarkan, berbicara, dan membaca. Dibandingkan dengan tiga kemampuan berbahasa yang lain, kemampuan menulis lebih sulit dikuasai bahkan oleh penutur asli bahasa yang bersangkutan sekalipun karena kemampuan menulis menuntut adanya penguasaan berbagai unsur kebahasaan dan unsur di luar bahasa yaitu unsur isi. Antara unsur bahasa dan unsur isi harus terjalin sedemikian rupa sehingga menghasilkan tulisan yang runtut dan padu.

Rendahnya kemampuan menulis peserta didik disebabkan oleh berbagai faktor. Cara guru membelajarkan peserta didik diduga menjadi salah satu faktor yang berperan besar dalam pengembangan kemampuan peserta didik. Guru yang jarang atau tidak pernah memberikan pelatihan dalam pembelajaran menulis akan menghambat pengembangan kemampuan menulis peserta didik. Hal ini terjadi karena menulis merupakan sebuah keterampilan yang akan dapat dikuasi dengan baik apabila banyak dilatihkan. Tidak mungkin tanpa dilatih menulis, peserta didik dapat menguasai keterampilan menulis dengan baik.

Faktor lain yang diduga turut mempengaruhi rendahnya kemampuan menulis peserta didik adalah faktor pengaruh bahasa pertama. Struktur ataupun kaidah bahasa pertama yang telah dikuasai dimungkinkan berpengaruh terhadap struktur bahasa yang sedang dipelajari atau bahasa target. Hal ini sejalan dengan hasil penelitian Watcharapunyawong \& Usaha (2012, p.67) yang berjudul Thai EFL Students' Writing Errors in Different Text Types: The Interference of the First Language bahwa kesalahan dalam menulis akibat gangguan bahasa pertama terdapat pada enam belas kategori. Keenam belas kategori tersebut adalah kata kerja yang menunjukkan waktu, pilihan kata, struktur kalimat, artikel, preposisi, modalitas, bentuk tunggal/ jamak, fragmen, bentuk kata kerja, kata ganti, 


\section{Ling Tera, 3 (1), May 2016 - 25 \\ Hanif Triyanto, Endang Nurhayati}

susunan kalimat, kata kerja pertama, konjungsi, kesesuaian subjek dan kata kerja, struktur paralel, dan perbandingan struktur .

Berdasarkan catatan dalam buku induk peserta didik, diketahui bahwa sebagian besar peserta didik SMP di Kabupaten Magelang adalah dwibahasawan. Mereka mengenal dan menggunakan bahasa Jawa dan bahasa Indonesia. Bahasa Jawa mereka kuasai dari orang tua dan lingkungan tempat tinggalnya sedangkan bahasa Indonesia mereka peroleh dari pembelajaran formal di sekolah. Dengan demikian dapat dikatakan bahwa sebagian besar peserta didik SMP di Kabupaten Magelang menggunakan bahasa Jawa sebagai bahasa pertama dan bahasa Indonesia sebagai bahasa kedua.

Kondisi masyarakat, termasuk peserta didik, di Kabupaten Magelang yang lebih banyak menggunakan bahasa Jawa daripada bahasa Indonesia ini menunjukkan adanya sikap positif terhadap bahasa Jawa. Sikap positif masyarakat terhadap bahasa daerah ini akan menimbulkan kecenderungan banyaknya unsur bahasa daerah yang terbawa ke dalam pemakaian bahasa kedua (Weinreich, 1979, p. 4). Kecenderungan pemakaian unsur-unsur bahasa Jawa tersebut diduga juga dapat terjadi dalam kegiatan pembelajaran bahasa Indonesia di sekolah.

Corder (Huda, 1981, p.1) mengatakan bahwa "pada hakikatnya belajar bahasa kedua bukanlah proses memperoleh bahasa baru, melainkan merupakan penambahan belajar sejumlah alternatif baru bagi subset aturan-aturan bahasa yang sudah diketahui". Proses belajar bahasa kedua (B2) tidak mungkin lepas dari faktor penguasaan bahasa pertama (B1). Penguasaan B1 akan ikut berperan dalam menentukan keberhasilan seseorang dalam mempelajari B2nya. Hal ini terjadi karena adanya persamaan dan perbedaan antara satu bahasa dengan bahasa yang lain. Chaer \& Agustina (2010, p.12) menyatakan bahwa selain bersifat unik, bahasa juga bersifat universal. Artinya, selain memiliki ciri atau sifat khas yang tidak dimiliki bahasa lain, bahasa juga memiliki ciri yang sama yang ada pada semua bahasa.

Sifatuniversal bahasa memberi kemudahan bagi pembelajar bahasa untuk menguasai B2-nya karena memungkinkan dilakukannya transfer langsung unsur atau kaidah B1 ke dalam B2. Transfer ini tidak akan menjadi masalah karena antara unsur bahasa yang ditransfer tersebut memiliki kesamaan kaidah atau aturan.
Dalam belajar B2, sering terjadi transfer unsur atau kaidah B1 ke dalam pemakaian B2. Oleh karena itu, dapat diprediksikan bahwa semakin besar perbedaan antara unsur atau kaidah B1 dengan B2, semakin besar pula kesalahan yang dialami peserta didik. Hal ini terjadi karena trasfer unsur atau kaidah bahasa yang berbeda akan menimbulkan kesalahan dalam berbahasa yang disebut interferensi.

Interferensi dapat terjadi ketika seorang dwibahasawan menggunakan B1-nya atau B2nya. Dengan kata lain, penguasaan B1 dapat mempengaruhi penggunaan B2 atau sebaliknya, ketika penutur menggunakanB1 dipengaruhi oleh penguasaan B2-nya, baik dari segi lafal (fonologi), kosakata (leksikal), pembentukan kata (morfologi) maupun struktur kalimatnya (sintaksis). Namun, interferensi biasanya terjadi dari bahasa yang dikuasai terlebih dahulu ke dalam bahasa yang dipelajari kemudian. Oleh karena itu, bagi peserta didik SMP di Kabupaten Magelang, peristiwa interferensi yang terjadi adalah dari bahasa Jawa ke dalam bahasa Indonesia.

Peristiwa interferensi merupakan salah satu faktor penyebab kurang berhasilnya pembelajaran bahasa Indonesia dari faktor pembelajar yang kurang memahami kaidah bahasa Indonesia.

Chaer (2009a, p.244) mengemukakan bahwa pembelajaran bahasa kedua kurang berhasil disebabkan oleh faktor kedisiplinan baik guru maupun murid.Dalam kegiatan belajar mengajar sehari-hari di kelas, peserta didik kadang mengalami kesulitan memahami materi yang dipelajari. Kesulitan pemahaman ini disebabkan oleh beberapa hal. Rendahnya kemampuan peserta didik dalam memahami bahasa dalam buku yang dipelajari diduga menjadi salah satu penyebabnya. Hal ini disadari oleh guru, sehingga guru berusaha untuk mencari alternatif bahasa yang dianggap lebih mudah dipahami oleh peserta didik. Asumsi bahwa B1 lebih dikuasai oleh peserta didik menjadi alasan bagi guru untuk menggunakannya walaupun terbatas pada unsur-unsur tertentu saja.

Interferensi penguasaan B1 terhadap penggunaan B2 akan_mengganggu peserta didik dalam upaya menguasai B2. Peristiwa interferensi yang mengganggu ini terutama bila terjadi pada tataran fonologi, morfologi, dan sintaksis. Pada tataran leksikal dan semantik, interferensi mempunyai andil besar dalam pengembangan suatu bahasa (Chaer \& Agustina, 2010, p.128). Oleh karena itu, interferensi yang 
bersifat mengganggu tersebut perlu diteliti untuk mengetahui faktor-faktor penyebabnya guna menemukan solusi untuk mengantisipasi terjadinya interferensi.

\section{METODE}

Penelitian ini termasuk jenis penelitian deskriptif kualitatif. Pendekatan kualitatif digunakan dalam penelitian ini karena analisis data tidak untuk menerima atau menolak hipotesis. Penelitian ini dilakukan di SMP Potensial di Kabupaten Magelang. Penelitian dilakukanpada semester ganjil yaitu bulan Agustus sampai dengan Oktober 2013.

Subjek penelitian ini adalah peserta didik kelas VIII SMP Negeri 3 Tempuran, SMP Negeri 2 Kajoran, dan SMP Negeri 2 Tegalrejo Kabupaten Magelang tahun 2013/2014. Jumlah karangan yang diteliti sebanyak 77 buah karangan laporan perjalanan. Objek penelitian berupa bentuk-bentuk interferensi bahasa Jawa dalam bahasa Indonesia pada tingkat kata, frasa, klausa, dan kalimat yang terdapat dalam karangan laporan perjalanan peserta didik kelas VIII beserta faktor penyebabnya.

Teknik yang digunakan untuk mengumpulkan data adalah teknik baca dan catat. Teknik ini dilakukan dengan cara membaca dengan cermat dan berulang-ulang karangan laporan perjalanan peserta didik selanjutnya mencatat bentuk-bentuk yang merupakan interferensi.

Instrumen utama dalam penelitian ini adalah peneliti sendiri (human instrument). Dengan pengetahuan, kepekaan, kecermatan, dan ketelitian, peneliti menggali dan menemukan datadata yang diperlukan sesuai dengan permasalahan penelitian. Instrumen lain yang digunakan berupa angket yang berisi 40 pertanyaan. Angket ini berisi pertanyaan untuk menggali informasi mengenai faktor-faktor penyebab terjadinya interferensi morfologi dan sintaksis bahasa Jawa dalam bahasa Indonesia.

Analisis data dalam penelitian ini dilakukan dengan menggunakan metode padan intralingual yaitu menghubungbandingkan unsur-unsur yang bersifat lingual, baik yang terdapat dalam satu bahasa maupun beberapa bahasa yang berbeda (Mahsun, 2011, p.118).

Teknik yang digunakan dalam metode padan intralingual pada penelitian ini adalah teknik hubung banding membedakan (HBB). Teknik ini dilakukan dengan menghubungkan dan membandingkan struktur atau kaidah bahasa Jawa dan bahasa Indonesia untuk mengetahui perbedan-perbedaannya sehingga dapat diketahui bila terdapat interferensi.

Adapun langkah-langkah yang ditempuh dalam teknik tersebut adalah (1) mengidentifikasikan kalimat-kalimat dalam laporan perjalanan yang di dalamnya terdapat interferensi, (2) mengklasifikasikan bentuk-bentuk interferensi ke dalam tataran morfologi dan sintaksis, (3) membandingkan kalimat-kalimat bahasa Indonesia yang terinterferensi dengan padanannya dalam bahasa Indonesia baku, (4) menginterpretasikan penyebab terjadinya interferensi morfologi dan sintaksis bahasa Jawa dalam bahasa Indonesia berdasarkan hasil analisis jawaban angket.

\section{HASIL DAN PEMBAHASAN}

Hasil analisis data yang berisi interferensi gramatikal bahasa Jawa ke dalam bahasa Indonesia mencakupi dua jenis yaitu interferensi morfologi dan interferensi sintaksis.

\section{Interferensi Morfologi}

Interferensi morfologi yang dimaksud dalam penelitian ini adalah interferensi yang terjadi karena penggunaan pola dan proses morfologis bahasa Jawa ke dalam bahasa Indonesia. Pada tataran morfologi, wujud interferensi bahasa Jawa ke dalam bahasa Indonesia meliputi interferensi pola proses morfologis dan interferensi pola proses morfofonemis.

\section{Intereferensi Proses Morfologis}

Dalam bahasa Indonesia terdapat tiga proses morfologis, yaitu pembubuhan afiks (afiksasi), pengulangan (reduplikasi), dan pemajemukan (komposisi) (Ramlan 2009, p.52, Muslich, 2010, p.35). Interferensi proses morfologis pada penelitian ini meliputi 15 tipe dengan 13 tipe afiksasi dan 2 tipe reduplikasi dan interferensi proses morfofonemis terdapat 1 tipe.

Berikut ini disajikan data dan pembahasan interferensi proses morfologis yang terdapat pada hasil karangan dalam pembelajaran menulis laporan perjalanan peserta didik kelas VIII SMP Negeri Potensial di Kabupaten Magelang.

Tipe I Penggunaan Prefiks $\{N-\}$ Bahasa Jawa untuk Membentuk Kata Kerja Aktif

Prefiks $N$ - BJ dapat beralomorf menjadi $/ \mathrm{m} /, / \mathrm{n} /, / \mathrm{ng} /$, dan /ny/. Prefiks $\{N-\}$ bahasa Jawa tersebut dalam bahasa Indonesia biasanya dinyatakan dengan prefiks meng-. Interferensi penggunaan prefiks $\{N-\}$ bahasa Jawa untuk membentuk kata kerja aktif dalam bahasa 


\section{LingTera, 3 (1), May 2016 - 27}

Hanif Triyanto, Endang Nurhayati

Indonesia yang ditemukan dalam karangan peserta didik kelas VIII SMP Negeri Potensial di Kabupaten Magelang berikut ini.

Penggunaan Prefiks $\{N-\}$ yang Beralomorf dengan $/ \mathrm{m}-/$

Interferensi morfologi tersebut dapat dilihat pada contoh berikut.

(1) Pas saya mau mancing belut tiba-tiba ada seorang nenek jatuh dari tangga. (021/KJ2/M/117)

Dalam bahasa Indonesia baku, penggunaan kata mancing tidak dibenarkan. Untuk menyatakan makna tersebut, dalam bahasa Indonesia digunakan kata memancing yang dibentuk dari dasar $\{$ pancing $\}+$ prefiks $\{$ meng- $\}$ beralomorf /mem-/ sehingga kalimat (1) dapat diperbaiki menjadi (1a) berikut.

(1a) Pada saat saya akan memancing belut tibatiba ada seorang nenek jatuh dari tangga.

Penggunaan Prefiks $\{N-\}$ yang Beralomorf dengan $/ \mathrm{n}-/$

Kata dalam bahasa Indonesia yang dibentuk dengan prefiks $\{N$ - $\}$ beralomorf dengan /n/ dapat dilihat pada kalimat (2)

(2) Pada hari kedua saya ikut nenek nanam padi. (019/TG2/M/165)

Kata nanam dalam kalimat (2) berasal dari kata dasar $\{$ tanam $\}+$ prefiks $\{N-\}$ yang beralomorf dengan fonem $/ \mathrm{n}-/$. Hal ini terjadi karena pengaruh bahasa Jawa nandur 'menanam'. Oleh karena itu, $\{$ tanam $\}+$ prefiks \{meng-\}seharusnya menjadi menanam sehingga kalimat (2) dapat diperbaiki menjadi (2a) berikut.

(2a) Pada hari kedua saya ikut nenek menanam padi.

Penggunaan Prefiks $\{N-\}$ yang Beralomorf dengan /ng/

Data dengan prefiks $\{N-\}$ beralomorf dengan /ng/ dapat dilihat pada contoh_data berikut.

(3) Saya dan warga langsung ngungsi ke tenda darurat. (021/KJ2/M/119)

Menurut Alwi, et al. (2003, p.110), jika prefiks $\{$ meng- $\}$ dilekatkan pada kata dasar yang berawal fonem /a/, /i/, /u/, /e/ atau /o/, bentuk $\{$ meng- $\}$ tidak mengalami perubahan dan tetap menjadi meng-. Oleh karena itu, $\{$ ungsi $\}+$ prefiks \{meng- $\}$ seharusnya menjadi mengungsi sehingga kalimat (3) dapat diperbaiki menjadi sebagai berikut.

(3a) Saya dan warga langsung mengungsi ke tenda darurat.

Penggunaan Prefiks $\{N-\}$ yang beralomorf dengan /ny/

Kata yang dibentuk dengan prefiks $\{N-\}$ beralomorf dengan /ny/ adalah sebagai berikut.

(4) Setelah aku dan teman-temanku sampai rumah, ibuku nyuruh aku dan temantemanku untuk makan. (025/KJ2/M/133)

Menurut Alwi, et al. (2003, p.112), jika prefiks \{meng- $\}$ dilekatkan pada kata dasar yang berawal fonem /c/, /j/, /s/ atau / $/$ s/, bentuk meng\} berubah menjadi meny-. Fonem /c/ dan /j/ yang berada pada awal kata tidak luluh sedangkan fonem $/ \mathrm{s} /$ dan $/ \check{\mathrm{s}} /$ yang berada pada awal kata akan luluh ke dalam fonem /ny/. Oleh karena itu, $\{$ suruh $\}+$ prefiks $\{$ meng- $\}$ seharusnya menjadi menyuruh sehingga kalimat (4) dapat diperbaiki menjadi:

(4a) Setelah aku dan teman-temanku sampai di rumah ibuku menyuruh aku dan temantemanku untuk makan.

Tipe II Penggunaan Prefiks $\{k e-\}$ Bahasa Jawa untuk $\{$ ter- $\}$ Bahasa Indonesia

Menurut Wedhawati, et al. (2010, p.125), prefiks $\{k e-\}$ dalam bahasa Jawa berfungsi membentuk kata kerja pasif intransitif dengan makna 'peristiwa yang diacu terjadi dengan tidak disengaja'. Fungsi dan makna prefiks $\{k e-$ \} bahasa Jawa tersebut memiliki kesamaan dengan fungsi dan makna prefiks $\{$ ter- $\}$ dalam bahasa Indonesia. Kesamaan ini tampaknya memberikan peluang bagi peserta didik untuk mempertukarkan penggunaan prefiks (ke-\} bahasa Jawa dengan prefiks $\{$ ter- $\}$ bahasa Indonesia tersebut tanpa memperhatikan asal muasal prefiks tersebut. Hal ini dapat dilihat pada contoh berikut.

(5) Aku kepleset di jalan karena jalannya licin. (009/KJ2/M/086)

Kata kepleset pada kalimat (5) tersebut merupakan kata kerja pasif yang tidak baku. Arti yang ditimbulkan oleh prefiks $\{k e-\}$ bahasa Jawa pun sama dengan arti prefiks $\{$ ter- $\}$ dalam bahasa Indonesia yaitu 'ketidaksengajaan'.Bila dinyatakan dalam bahasa Indonesia yang benar 


\section{LingTera, 3 (1), May 2016 - 28}

Hanif Triyanto, Endang Nurhayati

kata kepleset tersebut seharusnya menjadi terpeleset seperti dalam kalimat berikut.

(5a) Teman saya ada yang kehilangan sandalnya terbawa arus deras.

Tipe III Penggunaan Sufiks $\{-a n\}$ Bahasa Jawa untuk Membentuk Kata Benda 'tempat'

Sufiks $\{-a n\}$ hanya mempunyai satu fungsi, yaitu sebagai pembentuk kata nominal (Ramlan, 2009, p.154). Dalam bahasa Jawa, salah satu arti sufiks $\{-a n\}$ adalah menyatakan 'tempat yang tersebut pada bentuk dasar' (Wedhawati, et al., 2010, p.233). Misalnya paren 'tempat padi', suketan 'tempat rumput', sekolahan 'tempat bersekolah', dan sebagainya. Penggunaan sufiks $\{-a n\}$ dalam bahasa Jawa yang bermakna 'tempat yang tersebut pada bentuk dasar' perpengaruh pada pembentukan kata dalam bahasa Indonesia,, seperti dalam kalimat berikut.

(6) Kami berangkat dari sekolahan pukul 06.30. (005/TP3/M/006)

Bentuk yang benar menurut bahasa Indonesia baku adalah sekolah seperti pada kalimat berikut.

(6a) Kami berangkat dari sekolah pukul 06.30.

Tipe IV Penggunaan Sufiks $\{$-an $\}$ Bahasa Jawa untuk Membentuk Kata Kerja Intransitif $\{$ ber- $\}$ $+D$

Wedhawati, et al. (2010, p.142) menyatakan bahwa sufiks $\{-a n\}$ yang dilekatkan pada verba dasar dapat menyatakan arti 'bertindak seperti yang dinyatakan pada bentuk dasar dengan santai'. Proses pembentukan kata kerja bahasa Jawa dengan sufiks $\{-a n\}$ tersebut berpengaruh terhadap pemakaian bahasa Indonesia sebagaimana pada kalimat berikut.

(7) Di sekitar jalan ternyata banyak yang ikut liburan hari ini. (011/TP3/M/031)

Untuk menyatakan makna tersebut, dalam bahasa Indonesia baku digunakan verba intransitif $\{$ ber- $\}+D$ yaitu berlibur dan bertanding seperti pada kalimat (12a) berikut.

(7a) Di sekitar jalan ternyata banyak yang ikut berlibur hari ini.

Tipe V Penggunaan Konfiks $\{k e-/-a n\}$ Bahasa Jawa untuk Menyatakan Makna 'terlalu'

Penggunaan konfiks $\{k e-/-a n\}$ menyatakan 'apa yang tersebut pada bentuk dasar bersifat berlebihan atau terlalu D' (Wedhawati, et al., 2010, p.191), seperti contoh berikut.

(8) Kami tidak boleh kemalaman karena besuk pagi harus sekolah. (022/TP3/M/061)

Kata kemalaman termasuk kata yang mengalami interferensi bahasa Jawa dalam bahasa Indonesia. Dalam bahasa Indonesia baku tidak terdapat konfiks $\{k e-/-a n\}$ yang menyatakan makna 'terlalu' dan untuk menyatakan makna tersebut digunakan frasa terlalu $D$ sehingga kata kemalaman tersebut dinyatakan dengan terlalu malam seperti yang terlihat pada kalimat berikut.

(8a) Kami tidak boleh (pulang) teralu malam karena besuk pagi harus (masuk) sekolah.

Tipe I Penggunaan Konfiks $\{k e-/-a n\}$ Bahasa Jawa untuk Menyatakan Makna 'tidak sengaja'

Makna yang ditimbulkan oleh penggunaan konfiks $\{k e-/-a n\}$ pada kata bentukan tersebut adalah menyatakan 'peristiwa yang terjadi dengan tidak sengaja' (Wedhawati, et al., 2010, p.134).Hal ini dapat dilihat pada kalimat sebagai berikut.

(9) Saya di mobil ketiduran karena saya lelah. (015/KJ2/M/095)

Kata ketiduran pada kalimat (9) tersebut termasuk kata yang mengalami interferensi proses morfologi. Prefiks $\{$ ter- $\}$ dalam bahasa Indonesia berfungsi membentuk verba taktransisitif dengan arti 'menjadi dalam keadaan dasar tetapi bukan karena kemauan si pelaku' (Alwi, et al., 2003, p.145). Dengan demikian, kata ketiduran seharusnya ditulis menjadi tertidur seperti dalam kalimat berikut.

(9a) Saya di mobil tertidur karena saya lelah.

Tipe VII Penggunaan Prefiks \{peng- $\}$ Bahasa Indonesia pada Kata Dasar Bahasa Jawa

Dalam karangan peserta didik kelas VIII SMP Negeri Potensial di Kabupaten Magelang ditemukan kata penumpak seperti yang terlihat pada kalimat berikut.

(10) Dan dengan sangat kebetulan busnya sudah datang dan belum banyak penumpak. (024/TG2/M/176)

Prefiks \{peng- $\}$ berfungsi sebagai pembentuk kata benda dan dapat menyatakan beberapa arti. Salah satu arti yang ditimbulkan oleh prefiks \{peng-\} adalah 'orang yang melakukan perbuatan yang dinyatakan oleh verba' seperti 
pada kata pembeli, pengawas dan pengirim (Alwi, et al., 2003, p.225). Dalam bahasa Jawa juga terdapat nomina bentuk $\{p e-\}+D$ yang menyatakan arti 'yang melakukan perbuatan yang tersebut pada bentuk dasar', tetapi bentuk tersebut berasal dari bahasa Indonesia yang sudah sering digunakan dalam bahasa Jawa, seperti petani, petinju, dan pedagang. (Wedhawati, et al., 2010, p.229). Berdasarkan konteks kalimat (18), dapat diketahui bahwa prefiks peng- padakata penumpak juga digunakan untuk menyatakan arti 'orang yang naik'.

Dalam bahasa Indonesia baku, kata penumpak dinyatakan dengan bentuk $\{$ peng- $\}+$ $D$ yaitu penumpang, sehingga kalimat (10) tersebut dapat diperbaiki menjadi berikut ini.

(10a) Dengan sangat kebetulan busnya sudah datang dan belum banyak penumpang.

Tipe VIII Penggunaan Prefiks $\{$ ber- $\}$ Bahasa Indonesia pada Kata Dasar Bahasa Jawa

Dalam karangan peserta didik kelas VIII SMP Negeri Potensial di Kabupaten Magelang ditemukan kata bersalin seperti yang terlihat pada kalimat berikut.

(11) Setelah turun dari bus, kami langsung menuju ke tempat bersalin dan langsung ke kolam renang. (026/TG2/M/180)

Kata bersalin dibentuk dari verba bahasa Jawa salin 'ganti (pakaian)' + prefiks \{ber-\}. Dalam bahasa Indonesia, prefiks $\{$ ber- $\}$ dapat dilekatkan pada kata benda, kata kerja, kata sifat, dan kata bilangan dengan makna yang berbeda-beda. Jika dilekatkan pada dasar kata kerja atau kata benda yang dapat berstatus kata kerja seperti jalan, prefiks $\{$ ber- $\}$ berfungsi untuk menguatkan atau memformalkan status kata kerja tersebut (Alwi, et al., 2003, pp.137138). Dalam bahasa Indonesia baku, kata bersalin dinyatakan dengan bentuk $\{$ ber -$\}+D$ juga yaitu berganti, sehingga kalimat (11) dapat diperbaiki menjadi kalimat berikut.

(11a) Setelah turun dari bus, kami langsung menuju ke tempat berganti (pakaian) dan langsung ke kolam renang.

Tipe IX Penerapan Arti Prefiks $\{N-\}$ Bahasa Jawa pada Prefiks $\{$ meng- $\}$ Bahasa Indonesia

Prefiks \{meng- $\}$ bahasa Indonesia memiliki kemiripan dengan prefiks $\{\mathrm{N}-\}$ bahasa Jawa. Kedua prefiks tersebut memiliki bentuk fonemis dan arti yang serupa. Fungsinya pun sama yaitu sebagai pembentuk kata kerja aktif. Penerapan arti prefiks $\{\mathrm{N}-\}$ bahasa Jawa pada prefiks \{meng-\} bahasa Indonesia tersebut termasuk interferensi proses morfologis yang dapat dilihat pada kalimat berikut.

(12) Aku dan ayah diantar sama teman kakak dan aku dikasih uang 10.000 untuk mengangkot di sana. (020/KJ2/M/114)

Kata mengangkot pada kalimat (20) merupakan kata kerja aktif yang tidak baku. Untuk menyatakan makna tersebut, dalam bahasa Indonesia baku digunakan bentuk naik angkot sehingga kalimat (12) dapat diperbaiki menjadi berikut ini.

(12a) Aku dan ayah diantar oleh teman kakak dan aku diberi uang Rp10.000 untuk naik angkot di sana.

Tipe X Penghilangan Prefiks $\{$ meng- $\}$

Dalam ragam tulis, sering dijumpai adanya gejala penghilangan prefiks $\{m e-\}$ pada kata kerja aktif transitif. Peristiwa ini terjadi karena pengaruh pembentukan kata bahasa Jawa ke dalam pembentukan kata bahasa Indonesia seperti contoh berikut.

(13) Sesudah berenang kami beli makanan ringan. (005/TP3/M/009)

Kata beli kalimat (13) termasuk kata kerja aktif transitif. Dalam bahasa Indonesia baku, kata kerja aktif transitif diturunkan dengan menambahkan prefiks \{meng- $\}$ pada bentuk dasar yang berkategori verba (Alwi, et al., 2003, p.119). Oleh karena itu, kata beliseharusnya ditulis membeli seperti pada kalimat berikut.

(13a) Sesudah berenang, kami membeli makanan ringan.

Tipe XI Penghilangan Prefiks $\{$ ber- $\}$

Penggunaan kata kerja aktif intransitif yang berupa bentuk dasar ini dapat dilihat pada contoh berikut.

(14) Kami langsung ganti pakaian dan langsung berenang. (005/TP3/M/007)

Penggunaan kata ganti pada kalimat (14) termasuk interferensi dalam tataran morfologi, yaitu digunakannya bentuk BJ dalam BI. Sesuai kaidah BI baku, untuk memformalkan status kata kerja diperlukan penambahan prefiks $\{$ ber\} secara eksplisit (Alwi, et al., 2003, p.138). Oleh karena itu, kata ganti seharusnya ditulis menjadi berganti (pakaian). 


\section{LingTera, 3 (1), May 2016 - 30}

Hanif Triyanto, Endang Nurhayati

(14a) Kami langsung berganti pakaian dan langsung berenang.

Tipe XII Penghilangan Simulfiks \{ber-/-an $\}$

Dalam karangan mereka ditemukan kata monomorfemis jual yang seharusnya ditulis berjualan seperti pada kalimat berikut.

(15) Di perjalanan kami bertemu pengamen dan ada yang jual makanan ringan. (004/KJ2/M/070)

Kata jual pada kalimat (15) mengalami interferensi bahasa Jawa yang berupa penghilangan imbuhan $\{$ ber-/-an $\}$. Untuk menyatakan makna tersebut, dalam bahasa Indonesia baku digunakan bentuk $D+\{$ ber-/-an $\}$ yaitu berjualan seperti pada kalimat berikut.

(15a) Di perjalanan kami bertemu pengamen dan ada yang berjualan makanan ringan.

Tipe XIII Reduplikasi Penuh ( $\underline{\mathrm{Rp}})$ untuk Menggantikan Reduplikasi Sebagian (Rs) 'perbuatan santai'

Dalam karangan peserta didik kelas VIII SMP Negeri Potensial di Kabupaten Magelang terdapat kata ulang jalan-jalan seperti terlihat pada kalimat berikut.

(16) Dalam memperingati tahun baru aku dan keluarga besarku merental mobil untuk jalan-jalan ke Malioboro. (015/TP3/M/044)

Menurut Wedhawati, et al. (2010, p.145) salah satu arti reduplikasi penuh tersebut menyatakan 'ketidaktentuan tujuan atau arah tindakan dan tindakan itu dilakukan dengan santai' seperti kata ulang mlaku-mlaku 'berjalanjalan' dan mlayu-mlayu 'berlari-lari'.Dalam bahasa Indonesia baku, terdapat reduplikasi penuh dengan arti 'perbuatan yang dilakukan tanpa tujuan khusus' (Alwi, et al., 2003, p.149) seperti pada kata ulang mandi-mandi dan duduk-duduk. Untuk kata ulang jalan-jalan seharusnya dinyatakan dengan reduplikasi sebagian (Rs) ber- $D-D$ dan meng- $D-D$ sehingga menjadi berjalan-jalan seperti pada kalimat berikut ini.

(16a) Dalam memperingati tahun baru aku dan keluarga besarku merental mobil untuk berjalan-jalan ke Malioboro.

Tipe XIV Reduplikasi Penuh (Rp) untuk Menggantikan Reduplikasi Sebagian (Rs) 'perbuatan berkali-kali'
Dalam karangan peserta didik kelas VIII SMP Negeri Potensial di Kabupaten Magelang terdapat kata ulang nyari-nyari seperti terlihat pada kalimat berikut.

(17) Setelah nyari-nyari sampai lama ternyata ketemu juga. (019/TP3/M/050)

Menurut Wedhawati, et al. (2010, p.144) salah satu arti reduplikasi penuh dalam bahasa Jawa menyatakan 'perbuatan yang dilakukan berulang-ulang' seperti kata ulang iris-iris 'mengiris-iris' dan tudhing-tudhing 'menunjuknunjuk'. Dalam bahasa Indonesia baku, tidak terdapat reduplikasi penuh dengan arti 'perbuatan yang dilakukan berulang-ulang' dan untuk menyatakan makan tersebut digunakan bentuk $\{$ meng- $\}+D-D$ seperti memukul-mukul dan menari-nari sehingga kata ulang nyari-nyari pada kalimat (17) seharusnya dinyatakan dengan bentuk ulang mencari-cari seperti pada kalimat berikut ini.

(17a) Setelah mencari-cari lama ternyata menemukan juga.

Intereferensi Proses Morfofonemis

Proses morfofonemis menurut Alwi, et al. (2003, p.109-110) adalah "proses berubahnya suatu fonem menjadi fonem lain sesuai dengan fonem awal atau fonem yang mendahuluinya". Jadi, interferensi proses morfofonemis yang dimaksud dalam penelitian ini adalah interferensi yang terjadi karena penggunaan proses morfofonemis bahasa Jawa dalam proses morfofonemis bahasa Indonesia yang pada kaidah bahasa Indonesia distribusinya tidak lazim. Interferensi proses morfofonemis ini terjadi akibat peluluhan fonem awal kata dasar yang tidak tepat. Kata yang mengalami proses morfofonemis menurut proses morfofonemis bahasa Jawa yaitu kata nyari seperti pada kalimat berikut.

(18) Di perjalanan motor kakak saya macet dan nyari bengkel di mana-mana gak ketemu. (019/TP3/M/049)

Kata nyari dibentuk dari dasar bahasa Indonesia cari dibubuhi prefiks $\{N-\}$ bahasa Jawa. Berdasarkan kaidah pembentukan kata dalam bahasa Indonesia, fonem /c/ pada awal kata yang dibubuhi prefiks $\{$ meng- $\}$ tidak luluh dan fonem $/ \eta /$ pada prefiks \{meng-\} akan berubah menjadi /ñ/. Jadi, bentuk yang benar menurut kaidah BI baku bukan nyari, melainkan mencari. Dengan demikian, kalimat (18) dapat diperbaaiki menjadi berikut. 


\section{LingTera, 3 (1), May 2016 - 31}

Hanif Triyanto, Endang Nurhayati

(18a) Di perjalanan motor kakak saya macet dan (kami) mencari bengkel di mana-mana (tetapi) tidak menemukannya.

\section{Intreferensi Sintaksis}

Interferensi sintaksis adalah interferensi yang terjadi pada tataran frasa, klausa dan kalimat. Chaer \& Agustina (2010, p.124) menyatakan bahwa "Penggunaan serpihan kata, frasa, dan klausa di dalam kalimat juga dianggap sebagai interferensi pada tingkat kaimat". Tipe-tipe interferensi sintaksis tersebut dibahas berikut ini.

\section{Interferensi Pola Konstruksi Frasa}

Konstruksi Atributif $K B+\{-n y a\}+K B$

Yang dimaksud interferensi tipe konstruksi frasa atributif $K B+\{-n y a\}+K B$ dalam penelitian ini adalah kesalahan penggunaan konstruksi frasa BI yang mengikuti konstruksi frasa atributif bahasa Jawa.

(19) Di asramanya kakak peraturannya ketat sekali. (018/KJ2/S/110)

Sufiks $\{-e /-n e\}$ dalam bahasa Jawa sering dianggap sama dengan bentuk $\{-n y a\}$ dalam bahasa Indonesia. Alwi, et al. (2003, p.256) menyebut bentuk $\{-$ nya $\}$ sebagai pronomina persona ketiga yang menyatakan 'milik'. Konstruksi frasa pada kalimat (30) dapat dikembalikan kepada konstruksi frasa asalnya dalam bahasa Jawa, yaitu asramane mas/mbak 'asrama milik mbak/mas'.

Dalam bahasa Indonesia, Menurut Chaer (2009b, p.123), untuk menyatakan makna 'kepemilikan' tidak digunakan konstruksi $K B+$ $\{-n y a\}+K B$ tetapi dilakukan dengan cara menggabungkan unsur termilik dan unsur pemiliknya dengan konstruksi $K B+K B$ seperti rumah paman 'rumah milik paman'. Dengan demikian, dalam bahasa Indonesia baku frasa nominal asramanya kakak seharusnya ditulis menjadi asrama kakak seperti dalam kalimat berikut.

(19a) Di asrama kakak peraturannya ketat sekali.

\section{Konstruksi Atributif KS + sendiri}

Dalam karangan peserta didik kelas VIII SMP Negeri Potensial di Kabupaten Magelang terdapat frasa konstruksi atributif $K S+$ sendiri seperti cepat sendiri dan bagus sendiri seperti yang terlihat dalam kalimat (20) dan (21) berikut.
(20) Anak kelas VII A jalannya cepat sendiri. (010/TP3/S/028)

(21) Penampilan kelompok kami bagus sendiri. (003/TG2/S/139)

Frasa ajektival cepat sendiri dan bagus sendiri pada kalimat (20) dan (21) menunjukkan adanya interferensi sintaksis bahasa Jawa ke dalam bahasa Indonesia. Kalimat (20) dapat dikembalikan kepada struktur aslinya dalam bahasa Jawa yaitu Bocah kelas VII A mlakune paling cepet. Kalimat (21) jika dikembalikan ke bentuk asalnya dalam bahasa Jawa menjadi Tampilane kelomppokku apik dhewe. Kata sendiri pada kalimat (20) dan (21) merupakan terjemahan langsung dari kata dhewe bahasa Jawa sehingga perlu diperbaiki seperti kalimat berikut ini.

(20a) anak kelas VII A berjalannya paling cepat. (21a) Penampilan kelompok saya paling bagus.

Konstruksi Atributif saking $+K S+\{$-nya $\}$

Dalam karangan peserta didik kelas VIII SMP Negeri Potensial di Kabupaten Magelang ditemukan adanya frasa atributif saking $+K S+$ $\{-n y a\}$ seperti saking banyaknya dalam kalimat berikut.

(22) Pasir di pinggiran jalan menumpuk seperti gunung karena saking banyaknya tumpukan pasir. (015/TG2/S/161)

Penggunaan kata saking dalam konstruksi frasa tersebut dimungkinkan mengakibatkan terjadinya kekacauan atau kesulitan pemahaman bagi orang yang tidak memiliki pemahaman terhadap bahasa Jawa. Agar kalimat (22) tidak membingungkan pembaca, sebaiknya kata saking padafrasa saking banyaknya diganti dengan kata begitu sehingga frasa tersebut menjadi begitu banyaknya.

(22a) Pasir di pinggir jalan menumpuk seperti gunung karena begitu banyaknya.

Konstruksi Predikatif pada $+K K$

Pada karangan peserta didik kelas VIII SMP Negeri Potensial di Kabupaten Magelang ditemukan penggunaan frasa pada $+K K$ seperti pada pulang dan pada mentertawakan dalam kalimat berikut.

(23) Pada pukul 06.00 pagi saya bangun terus saya melihat di sekitar saya ternyata temanteman saya sudah pada pulang. (007/TP3/S/014) 


\section{Ling Tera, 3 (1), May 2016 - 32}

Hanif Triyanto, Endang Nurhayati

Wedhawati, et al. (2010, p.174) menyatakan bahwa dalam bahasa Jawa terdapat pola frasa verbal padha $+K K$ yang menyatakan makna 'kebersamaan tindakan atau proses yang dinyatakan pada konstituen inti'. Berbeda dengan bahasa Jawa, makna perbuatan jamak dalam bahasa Indonesia biasanya dinyatakan secara eksplisit. Apabila subjek kalimatnya bersifat jamak, $K K$ yang digunakan juga menyatakan jamak. Untuk menyatakan makna jamak tersebut, dalam bahasa Indonesia baku digunakan konstruksi frasa verbal (banyak yang) $+K K$, dengan catatan penggunaan kata banyak yang bersifat mana suka. Dengan demikian, frasa verbal pada kalimat (23) dapat dibetulkan menjadi (banyak yang) pulang seperti pada kalimat berikut.

(23a) Pada pukul 06.00 pagi saya bangun terus saya melihat di sekitar saya ternyata temanteman saya sudah (banyak yang) pulang.

\section{Konstruksi Predikatif lagi $+K K$}

Pada karangan peserta didik kelas VIII SMP Negeri Potensial di Kabupaten Magelang ditemukan penggunaan frasa lagi $+K K$ seperti lagi mengambili dalam kalimat berikut.

(24) Aku dan temanku melihat orang lagi mengambili kayu di hutan. (002/KJ2/S/068)

Menurut Wedhawati, et al. (2010, p.169), dalam bahasa Jawa terdapat frasa verbal dengan konstruksi lagi $+K K$ yang disebut frasa verbal keberlangsungan, yaitu frasa verbal yang modifikatornya menyatakan makna 'belum selesai atau masih berlangsungnya tindakan atau proses yang dinyatakan pada konstituen inti'. Dalam bahasa Indonesia baku, frasa lagi mengambili dapat diperbaiki menjadi sedang mengambili seperti dalam kalimat berikut.

(24a) Aku dan temanku melihat orang sedang mengambili kayu di hutan.

Interferensi Penggunaan Preposisi

Penggunaan Preposisi di dan pada Secara Tidak Tepat

Dalam karangan peserta didik kelas VIII SMP Negeri Potensial di Kabupaten Magelang dijumpai penggunaan frasa preposisional $d i$ dan pada secara tidak tepat seperti pada kalimat (25) dan (26) berikut.

(25) Di saat acara sudah dimulai saya dan teman-teman saya yang mengikuti acara inti sudah gemeteran. (003/TP3/S/004)
(26) Dalam perjalanan saya melihat-lihat pemandangan yang ada pada pinggir jalan. (021/TG2/S/166)

Ketidaktepatan ini tampak pada adanya ketidaksesuaian antara preposisi yang digunakan dengan kata yang mengikutinya.

Alwi, et al. (2003, p.295) menyatakan bahwa preposisi di digunakan untuk menyatakan 'tempat', dan pada untuk menyatakan 'waktu'. Chaer (2009b, pp.109-110) menambahkan bahwa preposisi pada juga dapat digunakan untuk menyatakan tempat yang berupa nama diri, nama jabatan, nama pangkat, nama perkerabatan, dan kata ganti orang. Selain di dan pada, terdapat juga preposisi dalam yang dapat digunakan untuk menyatakan 'tempat berada'. Oleh karena itu, kesalahan penggunaan frasa preposisional pada kalimat (25) dan (26) dapat diperbaiki menjadi pada saat, dan di pinggir jalan seperti pada kalimat berikut.

(25a) Pada saat acara dimulai, saya dan temanteman yang mengikuti acara inti sudah merasa gemetar. (003/TP3/S/005)

(26a) Dalam perjalanan, saya melihat-lihat pemandangan yang ada di pinggir jalan.

\section{Penggunaan Preposisi sama untuk oleh dan} dengan

Chaer (2009b, p.116) yang menggolongkan kata oleh dan dengan sebagai preposisi. Kesalahan penggunaan preposisi sama yang terdapat dalam karangan peserta didik kelas VIII SMP Negeri Potensial di Kabupaten Magelang dapat dilihat pada data kalimat berikut.

(27) Aku dan ayah diantar sama teman kakak dan aku dikasih uang 10.000 untuk mengangkot di sana. (020/KJ2/S/113)

(28) Saya sudah tidak kangen lagi sama nenek. (022/TG2/S/174)

Data (27) dan (28) menunjukkan adanya interferensi sintaksis bahasa Jawa dalam bahasa Indonesia yang berupa penggunaan preposisi sama secara tidak tepat. Dalam bahasa Indonesia baku, tidak terdapat preposisi sama. Berdasarkan uraian tersebut, data kalimat (27) dan (28) dapat diperbaiki menjadi berikut.

(27a) Aku dan ayah diantar oleh teman kakak dan aku diberi uang 10.000 untuk naik angkot di sana.

(28a) Saya sudah tidak kangen lagi dengan nenek. 


\section{LingTera, 3 (1), May 2016 - 33}

Hanif Triyanto, Endang Nurhayati

\section{Penggunaan Preposisidenganuntuk oleh}

Dalam bahasa Jawa terdapat preposisi karo yang dapat dipakai sebagai penanda hubungan 'tujuan', 'pelaku', 'perbandingan', 'kesambilan', dan 'kesertaan' (Wedhawati, et al., 2010, pp. 363-371). Banyaknya padanan kata karo dalam bahasa Indonesia dapat mengakibatkan kesalahan dalam penggunaan kata tersebut terutama bagi peserta didik yang berbahasa ibu bahasa Jawa. Kesalahan seperti ini juga terdapat dalam karangan peserta didik kelas VIII SMP Negeri Potensial di Kabupaten Magelang seperti berikut.

(29) Setelah sampai di sana kami disambut dengan riang gembira dengan nenek, kakak dan saudara. (002/TG2/S/137)

Dalam kalimat (29) terdapat kesalahan penggunaan preposisi dengan. Kesalahan ini terjadi karena kebiasaan peserta didik menggunakan bahasa Jawa yang berakibat pada kesalahan penggunaan padanan kata karo dalam bahasa Indonesia. Sebagai penanda hubungan 'pelaku', preposisi yang seharusnya digunakan dalam kalimat (29) adalah oleh tetapi yang digunakan oleh perseta didik adalah dengan. Kalimat (29) dapat dikembalikan kepada bentuk asalnya dalam bahasa Jawa menjadi Sakwise tekan kana, aku ditampa kanthi seneng karo simbah, mas/ mbak, lan sedulur. Jika kalimat tersebut diterjemahkan ke dalam bahasa Indonesia yang benar, menjadi seperti kalimat berikut.

(29a) Setelah sampai di sana, kami disambut dengan riang gembira oleh nenek, kakak, dan saudara.

Preposisi yang tepat digunakan sebagai penanda hubungan 'pelaku' dalam kalimat tersebut adalah oleh bukan dengan.

Interferensi Penggunaan Konjungsi

\section{Penggunaan Konjungsi sama untuk dan}

Selain sebagai preposisi, karo 'dan' dalam bahasa Jawa juga berfungsi sebagai konjungsi koordinatif penanda hubungan 'penjumlahan' (Wedhawati, et al., 2010, p.387). Kata karo 'dan' dikategorikan sebagai konjungsi karena kata karo dalam konteks kalimat yang akan dibahas ini memiliki padanan arti dengan kata dan yang tergolong sebagai konjungsi koordinatif yang menyatakan hubungan 'penambahan' (Alwi, et al., 2003, p.297). Data penggunaan konjungsi sama secara tidak tepat ini dapat dilihat pada kalimat berikut.
(30) Saya sama keluarga melihat keseniankesenian itu. (030/TG2/S/184)

Kalimat (30) tersebut bila diperbaiki menurut kaidah bahasa Indonesia yang benar menjadi seperti kalimat berikut.

(30a) Saya dan keluarga melihat keseniankesenian itu.

\section{Penggunaan Konjungsi terus untuk lalu, lantas}

Dalam bahasa Jawa kata terus merupakan konjungsi yang menyatakan hubungan makna 'perturutan' (Wedhawati, et al., 2010, p.389). Konjungsi terus memiliki padanan arti dengan lalu dan lantas dalam bahasa Indonesia. Meskipun ada padanan katanya dalam bahasa Indonesia, konjungsi terus ini masih sering digunakan dalam bahasa Indonesia. Penggunaan konjungsi terus seperti terlihat pada data (31) dan (32) berikut.

(31) Pada pukul 06.00 pagi saya bangun terus saya melihat di sekitar saya ternyata temanteman saya sudah pada pulang. (007/TP3/S/013)

(32) Teman-teman saya sudah masuk ke bus dan saya terus cepat-cepat masuk ke bus. $(016 / \mathrm{KJ} 2 / \mathrm{S} / 101)$

Makna yang ingin disampaikan oleh peserta didik dengan menggunakan kata terus adalah 'perturutan' yang sebenarnya sudah ada padanan katanya dalam bahasa Indonesia yaitu lalu atau lantas. Dengan demikian, kalimat (31) dan (32) dapat diperbaiki menjadi kalimat berikut.

(31a) Pada pukul 06.00 pagi saya bangun lalu melihat di sekitar ternyata teman-teman saya sudah pulang semua.

(32a) Teman-teman saya sudah masuk ke bus lalu saya cepat-cepat masuk ke bus.

Penggunaan Konjungsi biar untuk agar, supaya

Dalam bahasa Jawa terdapat beberapa konjungsi penanda hubungan 'tujuan'. Beberapa konjungsi tersebut adalah amrih 'agar', murih 'supaya', supaya 'supaya', kareben 'supaya', dan bene 'supaya' (Wedhawati, et al., 2010, p.398). Di antara beberapa konjungsi tersebut yang sering digunakan dalam bahasa sehari-hari adalah kata ben 'biar' sehingga kata biar sering digunakan untuk menyatakan hubungan 'tujuan'. Penggunaan konjungsi biar untuk menyatakan 'tujuan' tidaklah tepat karena terpengaruh bahasa Jawa. Kesalahan penggunaan konjungsi biar dapat dilihat pada karangan peserta didik 
kelas VIII SMP Negeri Potensial di Kabupaten Magelang berikut ini.

(33) Saya sampai di situ pas hujan lalu saya dan teman-teman turun dari mobil cari tempat biar gak kehujanan. (001/TP3/S/194)

Kesalahan penggunaan konjungsi biar untuk menyatakan tujuan disebabkan oleh interferensi penggunaan konjungsi ben dalam bahasa Jawa sehingga kalimat (33) dapat diperbaiki menjadi kalimat berikut.

(33a) Saya sampai di situ sedang hujan lalu saya dan teman-teman turun dari mobil cari tempat agar tidak kehujanan.

\section{Penggunaan Partikel Bahasa Jawa}

Berdasarkan fungsi gramatikalnya, partikel dalam bahasa Jawa dapat digolongkan ke dalam tiga jenis: (1) partikel gatra pelunak meliputi kok, mbok, (2) partikel gatra pelengkap meliputi dhing, je, ya, ta, dan (3) partikel pementing $t a$ (Wedhawati, et al., 2010, p.405). Partikel biasanya digunakan dalam ragam informal seperti dalam pergaulan sehari-hari. Kebiasaan peserta didik menggunakan bahasa Jawa dalam kehidupan sehari-hari ini berpengaruh terhadap penggunaan bahasa Indonesia tulis. Pengaruh itu salah satunya berupa penggunaan partikel bahasa Jawa kok oleh peserta didik dalam berbahasa Indonesia. Penggunaan partikel kok oleh peserta didik kelas VIII SMP Negeri Potensial di Kabupaten Magelang ini dapat dilihat pada kalimat (34) dan (35) berikut.

(34) Pemandangannya sangat bagus dan luas tetapi kok perutku terasa lapar sekali. (013/KJ2/S/088)

(35) Sampai di mbandongan kok mobilku habis bengsinnya. (013/KJ2/S/090)

Salah satu fungsi partikel kok dalam bahasa Jawa adalah menyatakan arti 'ketidakpercayaan' atau 'keheranan' (Wedhawati, et al., 2010, p.407). Jika dicermati, partikel kok dalam kalimat (34) dan (35) berfungsi menyatakan arti 'ketidakpercayaan' atau 'keheranan' karena peristiwa yang dialami yaitu perutku sakit dan mobilku habis bensinnya terjadi mendadak dan di luar perkiraan sehingga menimbulkan ketidakpercayaan atau keheranan. Agar sesuai dengan kaidah bahasa Indonesia yang benar, kalimat (34) dan (35) dapat diperbaiki seperti brikut.

(34a) Pemandangannya sangat bagus dan luas tetapi tiba-tiba perutku terasa lapar sekali. (35a) Sampai di Bandongan tiba-tiba mobilku habis bensinnya.

\section{Faktor Penyebab Terjadinya Interferensi Morfologi dan Sintaksis Bahasa Jawa ke dalam Bahasa Indonesia}

Berdasarkan analisis yang telah dilakukan terhadap karangan peserta didik kelas VIII SMP Negeri Potensial di Kabupaten Magelang yang berupa laporan perjalanan, ditemukan beberapa kesalahan. Sebagaimana dinyatakan Setyawati (2010, p.12) bahwa kesalahan berbahasa yang dilakukan peserta didik dalam suatu proses belajar mengajar mengimplikasikan tujuan pengajaran bahasa belum tercapai secara maksimal.

Kesalahan berbahasa akibat interferensi bahasa Jawa ke dalam bahasa Indonesia yang sering dilakukan oleh peserta didik hendaknya dapat dikurangi. Langkah awal untuk dapat memperbaiki kesalahan berbahasa akibat interferensi bahasa Jawa ke dalam bahasa Indonesia ini dapat dilakukan dengan mengidentifikasi faktor penyebab terjadinya interferensi. Tarigan (2011, p.98) menyatakan bahwa apabila ingin memperbaiki atau mengurangi kesalahan berbahasa peserta didik, sudah selayaknya terlebih dahulu mengetahui sumber atau penyebab kesalahan tersebut.

Upaya untuk mengetahui faktor penyebab interferensi morfologi dan sintaksis bahasa Jawa ke dalam bahasa Indonesia dalam menulis laporan perjalanan dilakukan dengan teknik pengisian angket oleh peserta didik. Berdasarkan data hasil pengisian angket, dapat diketahui adanya beberapa faktor yang menyebabkan terjadinya interferensi morfologi dan sintaksis bahasa Jawa ke dalam bahasa Indonesia dalam menulis laporan. Faktor yang menyebabkan terjadinya interferensi morfologi dan sintaksis bahasa Jawa ke dalam bahasa Indonesia dalam menulis laporan dapat dikelompokkan menjadi dua yaitu faktor linguistik dan faktor nonlinguistik. Faktor linguistik meliputi (1) penguasaan bahasa Jawa sebagai bahasa pertama, (2) rendahnya penguasaan bahasa Indonesia sebagai bahasa target, dan (3) kedwibahasaan peserta didik. Faktor nonlinguistik meliputi (1) kebiasaan, (2) lingkungan, (3) sikap bahasa, (4) motivasi belajar bahasa Indonesia, (5) guru sebagai pelaksana pembelajaran, dan (6) faktor evaluasi pembelajaran.

\section{SIMPULAN DAN SARAN}

Berdasarkan temuan hasil penelitian dan pembahasan sebelumnya dapat disimpulkan 
bahwa bentuk interferensi morfologi bahasa Jawa ke dalam bahasa Indonesia meliputi dua tipe yaiti interferensi proses morfologis dan interferensi proses morfofonemis.

Interferensi proses morfologis yang meliputi (1) pembentukan kata dengan prefiks $\{N-\}$ bahasa Jawa yang beralomorf dengan $/ \mathrm{m}-/$, /n-/, /ng-/, /ny-/ untuk membentuk kata kerja aktif; (2) penggunaan prefiks $\{k e-\}$ bahasa Jawa untuk \{ter-\}bahasa Indonesia; (3) penggunaan sufiks $\{-a n\}$ bahasa Jawa untuk membentuk kata benda 'tempat'; (4) penggunaan sufiks $\{-a n\}$ bahasa Jawa untuk membentuk kata kerja intransitif $\{$ ber- $\}+D$; (5) penggunaan konfiks $\{k e-/-a n\}$ bahasa Jawa untuk menyatakan makna 'terlalu'; (6) penggunaan konfiks $\{k e-/-a n\}$ bahasa Jawa untuk menyatakan makna 'tidak sengaja'; (7) penggunaan prefiks \{peng-\} bahasa Indonesia pada kata dasar bahasa Jawa; (8) penggunaan prefiks $\{$ ber- $\}$ bahasa Indonesia pada kata dasar bahasa Jawa; (9) penerapan arti prefiks $\{N-\}$ bahasa Jawa pada prefiks $\{$ meng- $\}$ bahasa Indonesia; (10) penghilangan prefiks \{meng-\}; (11) penghilangan prefiks $\{$ ber- $\} ;$ (12) penghilangan simulfiks $\{$ ber-/-an $\}$; (13) reduplikasi penuh untuk menggantikan reduplikasi sebagian 'perbuatan santai'; dan (14) reduplikasi penuh untuk menggantikan reduplikasi sebagian 'perbuatan berkali-kali'.

Interferensi proses morfofonemis hanya ditemukan satu kasus yaitu peluluhan fonem /c/ pada awal kata dasar yang mendapat prefiks $\{N$ \} secara tidak tepat.

Bentuk interferensi sintaksis bahasa Jawa ke dalam bahasa Indonesia meliputi empat tipe berikut. Tipe pertama adalah interferensi pola konstruksi frasa yang meliputi (1) konstruksi atributif $K B+\{-n y a\}+K B$; (2) konstruksi atributif $K B+$ sendiri; (3) konstruksi atributif saking $+K S+\{-n y a\} ;(4)$ konstruksi predikatif pada $+K K$; dan (5) konstruksi predikatif lagi + $K K$.

Tipe kedua adalah interferensi penggunaan preposisi yang meliputi (1) penggunaan preposisi di dan pada secara tidak tepat; (2) penggunaan preposisi sama untuk oleh, dengan; dan (3) penggunaan preposisi dengan untuk oleh.

Tipe ketiga adalah interferensi penggunaan konjungsi yang meliputi (1) penggunaan konjungsi sama untuk dan; (2) penggunaan konjungsi terus untuk lalu, lantas; dan (3) penggunaan konjungsi biar untuk agar, supaya.

Tipe keempat adalah interferensi penggunaan partikel bahasa Jawa dalam bahasa Indo- nesia. Tipe ini hanya ditemukan satu kasus yaitu penggunaan partikel bahasa Jawa kok.

Berdasarkan hasil analisis data angket, dapat disimpulkan bahwa faktor-faktor yang menyebabkan terjadinya interferensi morfologi dan sintaksis bahasa Jawa ke dalam bahasa Indonesia pada karangan hasil pembelajaran menulis laporan perjalanan peserta didik kelas VIII SMP Negeri Potensial di Kabupaten Magelang dapat dikelompopkkan menjadi dua yaitu faktor linguistik dan faktor nonlinguistik. Faktor linguistik, meliputi (1) penguasaan bahasa Jawa sebagai bahasa pertama; (2) rendahnya penguasaan bahasa Indonesia; dan (3) kedwibahasaan peserta didik.

Faktor nonlinguistik meliputi (1) kebiasaan peserta didik menggunakan bahasa Jawa; (2) lingkungan peserta didik; (3) sikap bahasa peserta didik; (4) motivasi peserta didik; (5) guru sebagai pelaksana pembelajaran; dan (6) evaluasi pembelajaran.

Beberapa saran yang dapat peneliti sampaikan adalah (1) agar pembelajaran menulis laporan perjalanan dapat mencapai tujuan yang diharapkan, pembelajaran terhadap aspek kebahasaan perlu mendapatkan perhatian yang memadai; (2) hasil penelitian ini baru merupakan tahap awal dalam upaya perbaikan pembelajaran bahasa Indonesia sehingga diperlukan penelitian lanjutan untuk meningkatkan keterampilan menulis peserta didik dengan memanfaatkan informasi dari hasil peneitian ini.

\section{DAFTAR PUSTAKA}

Alwi, H., et al. (2003). Tata bahasa baku bahasa Indonesia(edisi ketiga). Jakarta: Balai Pustaka.

Chaer, A. (2009a). Psikolinguistik kajian teoritik. Jakarta: PT Asdi Mahasatya.

Chaer, A. (2009b). Sintaksis bahasa Indonesia pendekatan proses. Jakarta: Rineka Cipta.

Chaer, A \& Agustina, L. (2010). Sosiolinguistik perkenalan awal. Jakarta: Rineka Cipta.

Iskandarwassid \& Sunendar, D. (2011). Strategi pembelajaran bahasa.Bandung: PT Remaja Rosdakarya Offset.

Mahsun. (2011). Metode penelitian bahasa: Tahapan strategi metode, dan tekniknya. Jakarta: PT Raja Grafindo Persada.

Muslich, M. (2010). Tata bentuk bahasa Indonesia kajian ke arah tata bahasa deskriptif. Jakarta: PT Bumi Aksara. 


\section{Ling Tera, 3 (1), May 2016 - 36}

Hanif Triyanto, Endang Nurhayati

Ramlan, M. (2009). Morfologi: Suatu tinjauan deskriptif. Yogyakarta: CV Karyono.

Setyawati, N.(2010). Analisis kesalahan berbahasa Indonesia: teori dan praktik. Surakarta: Yuma Pustaka.

Suryaman, M. (2012). Metodologi pembelajaran bahasa. Yogyakarta: UNY Press.
Watcharapunyawong, S. \& Usaha, S. (2012). Thai EFL students' writing errors in different text types: The interference of the first language. Diambil pada tanggal 17 November 2013, dari http://dx.doi.org/10.5539/elt.v6n1p67.

Wedhawati et al. (2010). Tata bahasa Jawa mutakhir (edisi revisi). Yogyakarta: Penerbit Kanisius. 